\title{
Erratum to: Comparative assessment between GR model and tank model for rainfall-runoff analysis using Kalman filter- application to Algerian basins-.
}

Mohamed Amireche ${ }^{1, \mathrm{a}}$, Tarek Merabtene ${ }^{2}$, Abdelmalek Bermad $^{3}$, and Djamel Boutoutaou ${ }^{4}$

${ }^{1}$ University of Oum El Bouaghi, Department of hydraulic, 04000 Oum El Bouaghi, Algeria

${ }^{2}$ University of Sharjah, Department of Civil and Environmental engineering, Sharjah, UAE

${ }^{3}$ ENPolytechnic, Department of hydraulic, 10 street Hassan.Badi-El harrach-Algeirs, Algeria

${ }^{4}$ University of Ouargla, Department of civil engineering, 30000 Ouargla, Algeria

Original article: MATEC Web of Conferences 120, 05006 (2017), DOI: 10.1051/matecconf/201712005006

The affiliation of authors should be replaced by the following text:

Mohamed Amireche ${ }^{1, \mathrm{a}}$, Tarek Merabtene ${ }^{2}$, Abdelmalek Bermad $^{3}$, and Djamel Boutoutaou ${ }^{4}$

${ }^{1,4}$ Laboratoire d'exploitation et de valorisation des ressources naturelles en zones arides, University of Ouargla, Algeria

${ }^{2}$ University of Sharjah, Department of Civil and Environmental engineering, Sharjah, UAE

${ }^{3}$ ENPolytechnic, Department of hydraulic, 10 street Hassan.Badi-El harrach-Algeirs, Algeria

\footnotetext{
${ }^{\mathrm{a} C}$ Correspondingauthor: amiremoh@hotmail.com
} 